\title{
Practical theology: A critically engaged practical reason approach of practice, theory, practice and theory
}

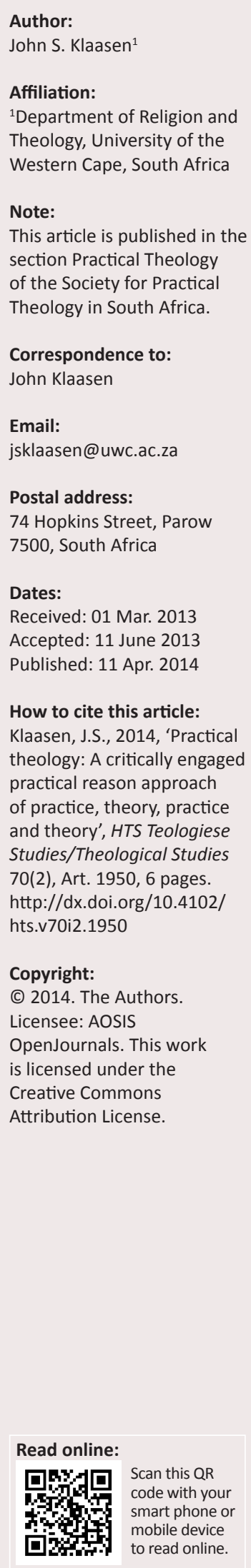

Browning's influential use of practical reason for his fundamental practical theology is analysed. His correlation of theory and practice in his three stages of theory, practice and theory is also critiqued because his approach reduces practical theology almost to professionalism and principles for ministry. His approach could also result in an antagonistic relationship between practice and theory as practice is reduced to theory or academics. This article seeks to present a critically engaged practical reasoning approach in which theory and practice have an in-ter-dependent relationship. Practical reason is an activity in which engagement happens at every stage. For this to happen, theory and practice interact as equal variables that have a bearing on each other not to reduce the one to the other, but to complement each other in a lateral hermeneutical process. This process has four stages, unlike Browning's three-stage correlation. The stages are schematically presented as practice, theory, practice and theory.

\section{Introduction}

Since the mid-eighties practical theology has attracted renewed interest from both theology and other sciences. Not only did practical theology become important for the church to interpret the increasing gap between modernity and post-modernity or between universalism and particularity, the gap between the autonomous individual and the communitarian persons, but also how rationality is used in practical theology. Rationality or more specifically abstract reasoning as meta-narrative has now lost its hold on both the sciences and theology. This article seeks to analyse and criticise Browning's approach of practical theology in light of its use of practical reason. In doing this I attempt to point out the significance of Browning's critical correlational approach to practical theology's renewed importance in post-modernity. Browning's approach is a starting point for developing my own model of practical theology which adds another dimension to Browning's approach.

Some of the most influential attempts by practical theologians to relate the church and the world have been the two distinct paradigms (Osmer 2011) and the foundational and postfoundational (Muller 2011) methods. Browning's approach is an attempt to relate theory and practice to the interaction of practical theology with the church and society by using practical reason. The correlation of theory and practice refers to the emergence of the importance of theory and practice and is presented as an interrelated relationship of practice, theory and practice.

Whilst Browning's critical correlational approach to practical theology forms the basis for some of the most influential approaches and scholars, this article will point out in which way reasoning in practical theology has been reduced to professionalism and principles for ministry in the church and the world. This way of using practical reason has also resulted in theory and practice having an antagonistic relationship because practice has been reduced to theory or intellectualism.

This article seeks to present a critically engaged practical reasoning approach to practical theology in which theory and practice have an in-ter-dependent relationship. Practical reason is an activity in which engagement happens at every stage. For this to happen, theory and practice interact as equal variables that have a bearing on each other, not to reduce the one or the other, but to complement each other in a lateral hermeneutical process. This process has four stages, unlike Browning's three-stage correlation. The stages are schematically presented as practice, theory, practice and theory with a reasonable 'distance' between each stage.

After an analysis and critique of Browning's approach I will present a critically engaged approach as a four-stage process for practical theology. In this approach both the practical and theoretical elements of practical theology are maintained, but each stage in the process is distinct, yet part of the whole, which makes them in-ter- dependent.

\section{Practice, theory and practice}

The approach of Browning will be discussed under the characteristics of being interdisciplinary, with the emphasis on practice, its inclusive task of church and world, and the role of ethics. 
The critical correlation approach is prevalent in Tillich, Tracy and Browning. Browning has extended Tracy's critique of Tillich's lateral approach to theology's relationship with social sciences. Whereas Tillich's three stage approach of autonomy, correspondence and interdependence makes theology the norm, Tracy's correlation approach acknowledges that both theology and social sciences need the correlation of questions and answers in a two-sided manner (Hestenes 2012:2). Browning (1985) builds on Tracy's critique as expressed in the following claim:

The revised method of correlation takes cultural practices seriously, not only as sources of questions to be answered by theology, but also as potential generators of alternative answers, which practical theology must critique and, in light of which, practical theology must be critiqued. (p. 18)

\section{Interdisciplinary}

The interdisciplinary method has become characteristic of Browning's approach to practical theology. Woodward and Pattison (2000) claim that an interdisciplinary approach:

uses the methods and insights of academic and other disciplines that are not overly theological as part of its theological method. Theology in itself, it is maintained, cannot reveal all that one needs to know adequately to respond to contemporary situations and issues. Thus economics, sociology, psychology, and other disciplinary findings and perspectives must be utilized. (p. 15)

Browning, in his doctoral thesis as far back as the mid-sixties correlates theories of:

the atonement of psychotherapy and using psychological analogies for the purpose of theological construction. In this bold way, Browning is apparently saying that psychotherapy is, to a large extent, the earthly model for the nature of God's healing activity. Psychotherapy is analogous to God and his healing activity. By studying psychotherapeutic healing processes, we can increase our understanding of the fundamental nature of God. Drawing on this analogy, Browning uses the correlation concept to show the relativeness of results. This demonstrates one of the strengths of the correlational approach as its openness towards a variety of relationships between Christian practice and contemporary practice. (Hestenes 2012:3)

Browning refers to the first possible relationship amongst different theories of psychology and theology, as one of identity. By this he means that the two can be saying the same thing. In other words there is a congruency about the results. The second form of relationship could be termed non-identical. This means that there is no agreement between the two kinds of relationships to the point of antagonism. Thirdly, there could be a high degree of analogy and perhaps many points of contact (Browning 1987:16).

Agreement or disagreement does not mean that the two kinds of relationships both come to the same or different conclusions or that either of them is true. The importance of relationships lies in the openness of theology and psychotherapy to further critique in order to reflect more comprehensively on its methods and goals with the view to address the needs of society more effectively. Here a tendency is displayed toward the goal of practical theology, but to a lesser extent than for example, by well-known practical theologians such as Schleiermacher. Browning is more concerned with the limits of practical theology from a theory-practice approach. He ascribes a greater role to practical theology than the mere application to the church community.

\section{Practice}

Browning (1991:43) clearly moves away from Tillich's approach when he ascribes to Tillich the theory-practicedichotomy approach. Browning's approach can be presented as practice-theory-practice. This implies that the emphasis is on practice rather than theory. In building on Tracy's mutual/ critical correlational approach, Browning suggests that all practical theology must start and end with practice. Also, whereas Tracy (1983:62) uses the subdivisions of theology as being fundamental, systematic and practical theology, Browning speaks of descriptive, historical, systematic and strategic practical theology. These sub-disciplines constitute fundamental practical theology which is 'the most inclusive understanding of theology' (Browning 1991:47). Following Schleiermacher's sequentialist movement Browning (1991) states:

Strategic practical theology is indeed the crown, as Schleiermacher said, of theology. But strategic theology is no longer the application to practice of the theoretical field of biblical, historical, and systematic theology as it was in the old Protestant quadrivium ... Strategic practical theology is the culmination of an inquiry that has been practical throughout. (p. 57)

\section{The task of practical theology}

Practical theology's task includes ministry to the church and the world. In another clear breakaway from the theory-practice dichotomy Browning develops Farley's idea of practical theology beyond clericalism. Farley (1983) recognises Schleiermacher's response to the Enlightenment movement as a reduction of theology to parochialism or clericalism. By this he means, according to Schleiermacher, the task and role of theology at a university is to train persons for the professional ministry of the church. To some extent this means the training of potential clerics, but to a more damning extent the training program of theology as science, for the ministry of the church and not the world (Browning 1983:26). Unlike the restriction of professionalism on clericalism and the church as put forward by Schleiermacher, a theology of care, according to Browning, would mean care by the professional for those in the church and in correlation with, for example, care of the larger society that goes beyond the confines of the church: 'Both the inner-ecclesial and public foci of these activities would be a part of the concerns of practical theology' (Browning 1985:16, 1991:57).

\section{The role of ethics}

Ethics forms a major part of the critical correlation approach. 'Both Tracy and I argued that theological ethics should play a privileged role in the clarification of the goals of Christian ethics' (Browning 1985:19). Theological ethics, according 
to Browning, has five dimensions. ${ }^{1}$ The visual dimension refers to the nature of the world and the context of human experience. The nature and context of the world might not always derive from abstract cognition, but metaphor, tradition and especially narratives help us to experience the world and describe it in its most natural way. The obligational dimension refers to the moral principles and common structures by which action takes place. Whereas narratives shape, influence and form, they do not provide principles of obligation. The tendency-need dimension refers to the needs of human nature. The fourth dimension is environmentalsocial or the context within which the experience takes place. The fifth dimension has to do with the actual or concrete rules and roles that are applied to the experience. These five dimensions are an attempt by Browning (1985:23) to present to the community and the individual guidelines 'to a way of moral being and thinking in the world'.

The five dimensional approaches to theological ethics derive directly from Browning's attempt to develop a comprehensive model for practical theology. The five dimensions have a direct link with Kant's categorical imperative and utilitarianism's 'obligation is the principle of utility' (obligational dimension), narrative theory (visual dimension), the naturalistic disciplines (tendencyneed), evolutionary theory and environmental ethics (environmental-social) and general rules (rules and roles dimension) (Browning 1985:26).

Hestenes (2012) sums up Browning's five dimensional approaches as hierarchically related and top-down from systematic theology, ethics and psychology to practical theology:

He shows a preference for beginning with the objective side of his methodological model ... and, after setting norms, moves to the objective or diagnostic parts of the model. He is thus concerned first with norming, then forming and then transforming. (p. 3)

\section{A critique of the critical correlational approach}

Combining three almost opposing approaches to ethics into a whole or at least continuum is as ambitious as it is risky. The narrative approach was born out of the weaknesses of the worldview of the Enlightenment. Narrative theory's sharp critique of the autonomous individual can hardly be combined with Kant's categorical imperative into one approach. The only way by which the five dimensions of ethics can be held as one is when the different dimensions are applicable independently to different stages of practice or if every dimension applies to every stage.

This is perhaps where Browning changed his five levels, in his earlier approach, to five dimensions in his later approach. Browning (1985:20-21) moves away from levels (although not completely) to dimensions because all five dimensions are so interwoven that they are generally found in moral thinking and moral action.

1.The five dimensions are discussed in detail in Browning (1991)
Moral thinking or moral reasoning as used by Browning refers to practical moral thinking or practical reasoning. Although rationality is given substantial space in at least the second dimension, Browning puts experience at least equal with reason in the quest for moral action. Reason is not limited to abstract reason or technical reason and it does not mean that practical theology is irrational. In other words practical theology makes use of reason as much as it values experience as authentic and normative. This is one of Browning's most significant contributions to the praxis and theory approach of practical theology.

Another affirmation of experience by Browning is the assertion that practical moral thinking is situated somewhere between the historicist and the radical empiricist. With regard to experience he claims that it teaches us nuances about ourselves that our cultural-linguistic traditions lead us to overlook or obscure' (Browning 1991:180).

Communitarian ethicists such as MacIntyre (1985) and Hauerwas (1983) remind us that experience is always interpreted from narratives of the past in which our knowledge is embedded. Issues such as equality and personhood are shaped by the stories of our lives of which current experience is merely a part.

Despite these major contributions to Browning's correlational approach, he does not put enough distance between experience and rationality. Browning still seems to give a privileged position to rationalisation that borders on abstract reasoning. By doing this, theory absorbs practice to the point where practice looses its value in the hermeneutical process.

Browning claims for example that practical reasoning has sub-moments. Firstly conventionality means to reason in the tradition that has been taught. Secondly we reconstruct our memory by using the current forms and meanings; we turn to the moments that provided the norms and ideals. Thirdly introspective induction reveals the genuine as opposed to the perceived needs. Fourthly the logic of comparison might discover that a new hypothesis must be tested by introspective induction. A further investigation of our needs might come from other sciences, like for example the experimental sciences that are, referred to as more objective empirical logic (Browning 1991:182-186).

If the above are sub-moments in practical reasoning then I would suggest that the moment in Browning's approach to practical reason is deontological ethics. This was already part of Browning's (1983) approach when he first took a correlational critical approach seriously:

Tracy, McCann, and I seem not so much opposed to an ethic of disposition as we are interested in both supplementing it by and possibly anchoring it on an ethic of principle. (p. 12)

By using both deontology and to some degree teleology is possibly showing the clearest distance between Schleiermacher and Browning. Whilst Browning gives a lot of attention to deontology (his main thesis seems clearly to 
be principle over disposition), he does not want to reject teleology. To keep these different approaches in correlation Browning opts for a consensus approach.

Browning's practical reason approach could easily be termed a consensus approach because of his attempt to combine the broad and sometimes opposing views and theories into a commonality. Theology and social science do not form a consistent unit which he terms sub-moments.

Browning's attempt to apply practical reason in the context of plurality presents another difficulty. Practical reason as he uses it in the critical correlation approach is in the very least fragmented and in its quest to form consensus it leaves questions unanswered which he does not deal with comprehensively.

He also affirms narrative theology, giving some degree of attention to tradition, but opts for a principle opposed to disposition. He attempts to keep these perceived opposites in tension by asking for consensus. Browning does not discard the hierarchical and coercive nature that acts as disguise for agreements.

Browning's ethical approach is also reductionist when he implies that practical theology - and more specifically pastoral care and counselling - is an ethical discourse and the formation in values and morals. Caps (1983), Fowler (1987) Poling and Miller (1985) are some of the critics of the reductionist approach. The Christian tradition and 'aspects of healing, sustaining, guiding and nurturing, do not give primacy to moral discourse at all times' (Hestenes 2012:7).

Following from his consensus seeking, Browning also does not provide a clear direction with regard to the resolve of the foundational and non-foundational debate. Whereas Browning (1985:17) coupled faith with reason for the sake of devising a public language for transmitting the message of the gospel in a global society (Browning 1985:17), Fowler seems more helpful by suggesting that faith is foundational even in pluralism:

At its heart, I believe, Christian faith calls persons to ways of seeing and being in the world that represent the fulfillment of what it means to be human. In ways that have integrity and reason when examined from the stand-point of other human perspectives, Christian faith sponsors growth toward full humanity. (Browning 1983:164)

Unlike Browning, Fowler opts for faith as opposed to practice as a priori for praxis in post-modernity. Drawing on Niebuhr's ${ }^{2}$ synthesis of historical-critical, sociological and psychosocial perspectives of faith, Fowler argues for faith as universal amidst the relativism, prevalent in post-modernity (Osmer \& Schweitzer 2003:237-239).

2.Faith for Niebuhr, was not limited to religious faith. He saw and illumined the relational structure of the kind of faith (or 'good faith') that makes the flourishing of stable communities of strangers and neighbours possible. Faith involves ties of mutual trust and loyalty between persons and groups who commit them, explicitly mutual trust and loyalty between persons and groups who commit them, explicitly
and tacitly, loyalty to and trust in shared centers of value and power' (Osmer \& and tacitly, loyalty to and
Schweitzer 2003:239).
Notwithstanding Browning's attempt to apply reason to practical theology and more specifically adding to the interplay between faith and reason, and his invaluable contribution against fideism, his emphasis on consensus leads to a lack of direction or normativity.

\section{Critical engaged practical reasoning Towards a practical theology of practice-theory- practice-theory}

Considering the weaknesses of the critical correlational approach (deontological) and its use of practical reason, I suggest a critically engaged practical reasoning approach for practical theology. This approach assumes that the four elements relate in an in-ter-dependent way in which none of the stages can function effectively without the other. And none of the stages is more superior to the other.

The four stages of practical reason can be explained by answering four questions. In the first stage the question is: What is currently going on. Put differently, what are the particular practices and experiences? This question, which is not unique to my developing model, attempts to analyse the situation as it is found in the present state. Osmer (2011:2 of 7), refers to this stage as the descriptive empirical task. It attempts to describe as fully as possible the actual experience encountered (Osmer \& Schweitzer 2003:2).

The primary focus is on practice and not theory. Whilst one cannot completely separate practice from theory, practice is substantial by nature and is not dependent on theory for its significance. Unlike Browning who almost reduced practice to theory, both ecclesial and public practice form the basis for this stage. In this stage we find for example the postfoundationalist approach, in which we are forced to listen to the narratives of the people in real life situations. Although this approach is hermeneutical in nature, 'it is reflective and situational embedded in epistemology and methodology' (Muller 2011:3). To emphasise this point Van Huyssteen (2006:19) says, 'embodied persons, and not abstract beliefs, should be seen as the locus of rationality. We as rational agents are thus always socially and contextually embedded.' Practice is informed by reason, but it is not consumed by reason, so that it keeps its validity.

Here the practices of the Christian community, for example worship, are practical, interactive, formative and social. These practices form the context of practical reason and have validity as a phenomenon that can influence both the subject who experiences and the object that is experienced. To put it differently there is a greater distance between practice and theory than the way in which Browning rationalises experience to the extent that practice becomes obsolete in the same way as Marx, Freud and Durkheim use symbols to explain religion as being functionalist.

The second question makes direct reference to the first. How do we make sense of the current practices? This question refers to the tools that are at our disposal to interpret 
particular experiences. This is of a more theoretical or abstract nature. By abstract I do not mean interpretation that is completely objective, but abstract in the sense that there is a degree of subjectivity. In applying hermeneutical tools such as reason and experience the subject has a level of interaction with the tools that are used for making sense.

Practical reason becomes engaged reasoning. Engaged reasoning is not technical or abstract reason, but enters into a relationship with experiences as a tool of interpretation. The relationship is one of interaction. Engaged reason itself is not an abstract phenomenon, but as both an independent and a dependent variable helps to make sense of current experiences by forming and being informed. Reason does not reduce experience to theory, as Tracy and subsequently Browning do in the application of the theory-laden phrase. Whilst I agree that theory and practice are closely associated, I allow more distance between the two. Reason as a theoretical phenomenon enters with experience into a mutually enriching way.

The third question refers to the transformed experience. What ought the experience to be? This stage reflects the transformed experiences of persons. Ideals and highest good are developed. A distinction is made between right and wrong, appropriate and inappropriate, good and bad, acceptable and unacceptable and pleasure and pain. This stage is about the shaping of subjects and developing of sustainable circumstances. It includes an evaluation of particular experiences with other experiences with the openness to influence and be influenced. Practical reason is not only descriptive, but it unravels that which is normative.

The fourth stage asks the question: How do we make sense of these transformed experiences? Here tradition plays an important role. Blondel, a lay Catholic theologian, developed the theory 'in which action was seen as a source of understanding' (Dulles 1992:92). For Blondel, tradition is not only about the transmission of facts, but it includes critical engagement. In placing his theory between the dogmatism of the Scholastics also known as the Procrustean and the historicism of the modernists, called Protean, his synthesis suggests tradition as the transmission of the 'lived reality of the past' (Dulles 1988:83).

The tradition of the Christian community becomes normative because of its truthfulness to the past. It is at this stage that the narratives of the community engage with the experience (empirical). In this engagement we make sense of the transformed experiences of the community.

\section{Conclusion}

Practical theology has emerged in the last three decades as an important theology to address the continuous changing social environment. Practical theology attempts to answer the question: How do Christians make sense in an ever-increasing secular society? One way of answering the question is to say that practical theology draws on practical reason to answer the more fundamental question: What is going on? Practical reasoning helps with the analyses. Browning without doubt one of the influential scholars of his time, has attempted to answer this question by using reason. Browning has also gone beyond that and answered the more encompassing question: What ought to be going on? Browning has pointed out how universal principles enable the church to be more effective by interacting in a mutually enriching way with experience, tradition and other disciplines. Ministry and theology is primarily public (Tracy).

A critically engaged practical reason approach suggests that practical theology addresses the social environment by analysing current particular experiences and making sense of these through the application of tools such as reason and experience. Transformed experiences are explained by drawing on tradition and narratives of the community. Practical reason is the critical engagement of these various elements (e.g. experience, faith, tradition and narratives) at every stage of the lateral process. Each of the stages forms an in-ter-dependent relationship when it 'looks back' to the former stage for a more comprehensive meaning-making.

Practical reason is critical engagement of the community, the particular experience and tradition. Community refers to the Christian community which is bound together in the Trinitarian God. The particular refers to the validity and value in its particular contexts and experience. The tradition is that which is rehearsed in the worship and in particular the re-enactment of the Lord's Supper. Unlike the application of universal principles in an abstract way, a critically engaged practical reason takes consequence and context seriously.

\section{Acknowledgements Competing interests}

The author declares that he has no financial or personal relationship(s) that may have inappropriately influenced him in writing this article.

\section{References}

Browning, D.S. (ed.), 1983, Practical theology: The emerging field in theology, church and world, Harper \& Row, Publishers, San Francisco, CA.

Browning, D.S., 1985, 'Practical theology and political theology', Theology Today 42(1), 15-33. http://dx.doi.org/10.1177/004057368504200104

Browning, D.S., 1987, Religious thought and the modern psychologies: A critical conversation in the theology of culture, Fortress Press, Philadelphia, PA.

Browning, D.S., 1991, A fundamental practical theology, Fortress Press, Minneapolis, $\mathrm{MN}$.

Capps, D., 1983, Life cycle theory and pastoral care, Westminster, Philadelphia, PA.

Duke, J.O. \& Stone, H. (eds.), 1988, Christian caring: Selections from practical theology, Fortress Press, Philadelphia, PA.

Dulles, A., 1988, The reshaping of Catholicism: Current challenges in the theology of the church, Harper and Row, San Francisco, CA. Dulles, A., 1992, The craft of theology: From symbol to system, Crossroads, New York,
NY.

Farley, E., 1983 'Theology and practice outside the clerical paradigm', in D. Browning (ed.), Practical theology, pp. 21-41, Harper and Row, San Francisco, CA.

Fowler, J., 1987, Faith development and pastoral care, Fortress, Philadelphia, PA.

Hauerwas, S., 1983, The peaceable kingdom: Primer in Christian ethics, University of Notre Dame Press, London.

Hestenes, M., 2012, 'The early Browning: Pastoral care in a pluralistic age and the method of practical moral inquiry', HTS Teologiese Studies/Theological Studies $68(2), 7$ pages. http://dx.doi.org/10.4102/hts.v68i2.1211 
Maclntyre, A., 1985, After virtue: A study in moral theory, Gerald Duckworth and Company, London.

Muller, J.C., 2011, 'Postfoundational practical theology for a time of transition', HTS Teologiese Studies/Theological Studies 67(1), 1-5. http://dx.doi.org/10.4102/hts. v67i1.837

Osmer, R.R., 2011, 'Practical theology: A current international perspective', HTS Teologiese Studies/Theological Studies 67(2), 7 pages. http://dx.doi.org/10.4102/ hts.v67i2.1058

Osmer, R.R. \& Schweitzer, F. (eds.), 2003, Religious education between modernization and globalization: New perspectives on the United States and Germany, William B. Eerdmans Publishing Company, Grand Rapids, MI.
Poling, J. \& Miller, D., 1985, Foundations for a practical theology of ministry, Abingdon, Nashville, TN.

Reader, J., 2008, Reconstructing practical theology: The impact of globalization, Ashgate, Hampshire.

Tracy, D., 1983, 'The foundations of practical theology', in D. Browning (ed.), Practica theology, pp. 61-82, Harper and Row, San Francisco, CA.

Van Huyssteen, J.W., 2006, Alone in the world? Human uniqueness in science and theology. The Gifford Lectures, William B. Eerdmans Publishing Company, Grand Rapids, MI.

Woodward, J. \& Pattison, S., 2000, The Blackwell reader in pastoral and practical theology, Blackwell publishers, Oxford. 